\title{
Preliminary Study on the Role of Ionic Calcium in Gelation and Proteolysis of UHT Milk
}

\author{
Chove Lucy Mlipano \\ Sokoine University of Agriculture (SUA), Department of Food Technology, Nutrition \\ and Consumer Sciences, P. O.Box 3006, Morogoro, Tanzania \\ E-mail: lucychove@suanet.ac.tz; lucychove@yahoo.co.uk \\ Lewis Michael \\ University of Reading (UoR), Department of Food and Nutritional Sciences, P.O. Box \\ 226, Reading RG6 6AP, UK \\ E-mail:m.j.lewis@reading.ac.uk
}

Received: July 9, 2017 Accepted: December 26, 2017 Published: December 28, 2017 doi:10.5296/jfs.v7i1.12081ＵRL: https://doi.org/10.5296/jfs.v7i1.12081

\begin{abstract}
A study was conducted to determine the influence of ionic calcium on gelation and proteolysis in milk. Raw milk was heated to $142{ }^{\circ} \mathrm{C}$ for $2 \mathrm{~s}$ followed by cooling to $5^{\circ} \mathrm{C}$ to make UHT milk. Two sequestering agents, Trisodium citrate (TSC) and Sodium hexametaphosphate (SHMP) were added at $0.04-0.08 \%(\mathrm{w} / \mathrm{v})$ to the processed UHT milk to reduce the ionic calcium levels. Proteolysis and gelation were induced by addition of trypsin (248 BAEE units), $0.03 \%$ (v/v) chymosin and $10^{6} \mathrm{cfu} / \mathrm{mL}$ Pseudomonas fluorescens NCIMB 702085 (Ps. fl. 416) to UHT milk. Samples were stored at $25{ }^{\circ} \mathrm{C}$ for $2 \frac{1}{2}$ weeks to monitor gelation and $\mathrm{Ca}^{2+}$ and some were incubated at $37{ }^{\circ} \mathrm{C}$ for $2 \mathrm{~h}$ to monitor proteolysis. SHMP reduced more $\mathrm{Ca}^{2+}$ than TSC. $\mathrm{Ca}^{2+}$ reduction was accompanied by an increase in $\mathrm{pH}$, most evident with TSC at $25^{\circ} \mathrm{C}$. Gelation was not observed in samples inoculated with Ps. fl. 416 (with sequestering agents) even after 9 days of storage, suggesting the importance of calcium in gelation. Chymosin treated samples gelled on day 0 , whereas other samples gelled after 4 days. Trypsin increased $\mathrm{Ca}^{2+}$ to levels higher than originally present in control UHT skim milk. Although in the current study, proteolysis was higher in samples inoculated with Pseudomonas fluorescens 416, no clear relationship was established between proteolysis and gelation in UHT milk. This observation
\end{abstract}




\section{$\triangle$ Macrothink}

implies that proteolytic activity is not influenced by $\mathrm{Ca}^{2+}$. However, longer time study using sodium azide to prevent bacterial contamination would be required to confirm these findings.

Keywords: Chymosin, Gelation, Ionic Calcium, Proteolysis, Pseudomonas fluorescens, Sodium hexametaphosphate (SHMP), Trypsin, Trisodium citrate (TSC)

\section{Introduction}

Calcium in milk is significant for both its nutritive value and its key role in many functional properties of milk and milk products. Manipulating its concentration, particularly of the ionic form, alters the properties of the products and facilitates or hinders certain processing operations. Stability to thermal treatment is the major property affected, but several others such as gelation, coagulation and foaming are influenced by either adding or removing calcium (Deeth \& Lewis, 2015; Faka et al., 2009). Calcium in milk is partitioned between the serum $(30 \%)$ and colloidal phase of milk (70\%). Total calcium in milk is around $30 \mathrm{mM}$, of which about $2 \mathrm{mM}$ is ionic calcium (Holt et al., 1981). Though ionic calcium in milk is low, it is essential for stability of casein micelles and influences clotting of milk and precipitation of colloidal calcium phosphate (CCP). It is essential for gelation of milk by rennet during cheese manufacture (Tsioulpas, 2005; Hyslop, 2003). In addition, a minimum concentration of ionic calcium is necessary for aggregation of casein micelles (Manji et al., 1986; Manji \& Kakuda, 1988; Van Hooydonk et al., 1986). Gelation in UHT milk is one of the most common problems encountered in the dairy industry (Datta \& Deeth, 2001). A gel is a three dimensional protein matrix formed during heating by the $\beta$-lactoglobulin interacting with $\kappa$-casein to form $\beta-\kappa$ complexes. Proteases cleave the peptide bond which anchors $\kappa$-casein to the casein micelle, facilitating the release of $\beta-\kappa$ complexes from the micelle. Aggregation of $\beta-\kappa$ complexes forms a three-dimensional network of cross-linked proteins which produce a gel when a critical concentration is reached (Datta \& Deeth, 2003). A study revealed that removal of calcium caused prolonged coagulation and production of a weaker gel which was accompanied by ionic calcium reduction (Sharma \& Sindhu, 2001). To examine the role of ionic calcium in gelation and proteolysis, it was reduced in heated milk by two sequestering agents. The effect of ionic calcium reduction and its effect on gelation and proteolysis were studied in milk samples with added trypsin, chymosin and Pseudomonas fluorescens 416.

\section{Materials and Methods}

\subsection{Processing of UHT Milk}

Raw milk was processed on an APV junior UHT plate heat exchanger with two stages of heating involving hot water $\left(80^{\circ} \mathrm{C}\right)$ and steam $\left(112-144^{\circ} \mathrm{C}\right)$. A constant flow rate was used, giving a residence time of $2 \mathrm{~s}$ in the holding tube as described in detail by Browning et al. (2001). Homogenisation took place between the heating stages at about 170 bar. Raw milk was heated at $142{ }^{\circ} \mathrm{C}$ for $2 \mathrm{~s}$. This was followed by cooling and storage at $2{ }^{\circ} \mathrm{C}$ prior to laboratory analysis.

In a preliminary experiment, two sequestering agents TSC and SHMP were initially each added at $0.5 \%, 1 \%, 1.5 \%$ and $2 \%(\mathrm{w} / \mathrm{v})$ to UHT milk. These levels corresponded to TSC (1.36, 2.72, 3.4, 6.8 and $1.02 \mathrm{mM})$ and $\operatorname{SHMP}(0.65,1.31,1.63,3.27$ and $4.9 \mathrm{mM})$. Samples were thoroughly mixed using magnetic stirrers for $30 \mathrm{~min}$. Preliminary results indicated that more 


\section{MInstitute Macrothink $_{\text {Int }}$}

than $40 \%$ calcium had been reduced and hence lower levels of sequestering agents $(0.04$ $0.08 \%$ ) were proposed and used.

\subsection{Samples Inoculation}

The mechanism of gelation by trypsin (10,100 units/ mg protein; Sigma-Aldrich St Louis, USA), chymosin (chymax Plus batch 071101, Hansen, Denmark) and Pseudomonas fluorescens NCIMB 702085 (416) were obtained from the departmental stock culture, maintained at $-80{ }^{\circ} \mathrm{C}$ were studied. This was done by adding $8.705 \times 10^{-3}$ Units of trypsin equivalent to 248 BAEE units, $0.03 \%(\mathrm{v} / \mathrm{v})$ chymosin and $10^{6} \mathrm{cfu} / \mathrm{mL}$ Pseudomonas fluorescens 416 to heated milk. Samples were stored at $25^{\circ} \mathrm{C}$ for $2 \frac{1}{2}$ weeks to monitor gelation and ionic calcium concentration and some were incubated at $37^{\circ} \mathrm{C}$ for $2 \mathrm{~h}$ to study proteolysis.

\subsection{Ionic Calcium Monitoring}

Ionic calcium levels were measured was carried out at room temperature $\left(20 \pm 0.5{ }^{\circ} \mathrm{C}\right)$ using a minimum of $35 \mu \mathrm{L}$ sample before inoculation of the agents and after incubation (except gelled samples and samples inoculated with Pseudomonas fluorescens 416) by a Ciba corning 634 ISE $\mathrm{Ca}^{2+} / \mathrm{pH}$ analyser (Bayer Ltd., Newbury,UK. The electrodes were washed with a deproteinising solution (Siemens Medical solutions Diagnotics Tarrytown, New York, USA) containing active pepsin diluted in a solution containing $\mathrm{NaCl}, \mathrm{KCl}, \mathrm{CaCl}_{2}, \mathrm{LiCl}$ and $\mathrm{HCl}$ and a conditioning solution (Siemens Medical solutions Diagnotics Tarrytown, New York, USA) consisting mainly of $\mathrm{NaCl}$. Standardisation by $\mathrm{Ca}^{2+}$ standard solution $(1.25 \mathrm{mM})$ was automatically performed daily. A calibration curve was constructed by using known calcium standards of $0.5,1.0,1.5,2.0,2.5$ and $3.0 \mathrm{mM}$. Three readings (in $\mathrm{mV}$ ) were taken, averaged and plotted against $\log (\mathrm{Ca}) \mathrm{mM}$. The concentration of calcium was obtained from the equation of the calibration curve. Results from the standards are given in Appendix 1.

\subsection{Gelation Monitoring}

To study the effect of ionic calcium reduction on gelation, samples with added trypsin (248 BAEE units), chymosin (0.03\%) and inoculated with Pseudomonas fluorescens $416\left(10^{6} \mathrm{cfu}\right.$ per $\mathrm{mL}$ ) were monitored and recorded daily. Gelation was indicated by the high resistance of milk to flow when poured out from the container.

\subsection{Proteolysis Monitoring}

\subsubsection{The Effect of Ionic Calcium Reduction on Proteolysis}

Proteolysis of reduced ionic calcium sample was induced by incubating them at $37{ }^{\circ} \mathrm{C}$ for $2 \mathrm{~h}$ followed by clarification to obtain $6 \%$ Trichloroacetic acid (TCA) and $\mathrm{pH} 4.6$ soluble extracts. Fifty $\mathrm{mL}$ warm water $\left(40^{\circ} \mathrm{C}\right)$ was added to $5 \mathrm{~mL}$ of milk followed by $0.5 \mathrm{~mL} 10 \%(\mathrm{w} / \mathrm{v})$ acetic acid. After standing for 10 minutes, $0.5 \mathrm{~mL} 1 \mathrm{M}$ sodium acetate was added and placed in cold water for 10 minutes before filtration through Whatman no. 41 filter paper and washing and making up to $100 \mathrm{~mL}$. The clear extracts obtained were further filtered by $0.2 \mu \mathrm{m}$ Millipore filter before being subjected to the RP-HPLC method to determine breakdown products. All samples were analysed in triplicates.

\subsubsection{Reverse Phase High Performance Liquid Chromatography (RP-HPLC)}

Analysis by HPLC was performed on a Dionex chromeleon equipment consisting of a P580 pump (Dionex corporation, Munchen, Germany) with a photodiode array detector (Dionex PDA-100, Munchen, Germany), an automated sample injector a STH 585 version 2.5 HPLC 


\section{Ml Macrothink}

column compartment with $150 \times 4 \mathrm{~mm}$ reverse phase column (SGE 150 GL4-C-P-8/5, Australia) at $40{ }^{\circ} \mathrm{C}$. Data analysis was computed by the Chromeleon Datasystem software $\mathrm{v}$. $6.50 \mathrm{SP} 4$ Build 1000 . The flow rate was $0.75 \mathrm{~mL} / \mathrm{min}$ and detection was by a UV/Vis detector at $210 \mathrm{~nm}$. Solvent A was $0.1 \%(\mathrm{v} / \mathrm{v})$ trifluoroacetic acid (TFA) in HPLC grade water whereas Solvent B was $0.1 \%(\mathrm{v} / \mathrm{v})$ TFA in HPLC-grade acetonitrile. The volume injected was $50 \mu \mathrm{L}$. During the first 25 minutes, solvent B was increased from $15 \%$ to $35 \%$. After 5 min, it was increased to $100 \% \mathrm{~B}$ and held for $10 \mathrm{~min}$. The column was then equilibrated at $15 \% \mathrm{~B}$ for 10 min in readiness for the next sample injection.

\subsection{Statistical Data Analysis}

Data was-analysed using excel program for Analysis Of Variance (ANOVA) and simple regression analysis. All analyses were carried out in triplicates, and results were expressed as mean \pm standard deviation (SD).

\section{Results}

\subsection{Effect of Sequestering Agents on Calcium Reduction}

Table 1, 2 and 3 show results of preliminary trials to assess the optima concentration of agents in reducing ionic calcium. It shows that there was more than $50 \%$ reduction of calcium $(76.9 \%$ and $53.7 \%$ ) respectively by $8.17 \mathrm{mM}$ SHMP and $17 \mathrm{mM}$ TSC respectively as shown on Table 1. The reduction levels were high and hence lower levels were proposed to cause not more than $20 \%$ reduction of ionic calcium.

A second trial with reduced agents concentration showed respective reduction of $44.4 \%$ by $3.40 \mathrm{mM}$ TSC and $53.8 \%$ by $1.63 \mathrm{mM}$ SHMP (Table 2) leading to further attempt use lower concentrations of sequestering agents so as to establish the lowest ionic calcium reduction that would promote gelation.

Further concentration reduction to $1.36 \mathrm{mM}$ for TSC and $0.65 \mathrm{mM}$ for SHMP caused 17.36 and $19.6 \%$ reduction of ionic calcium respectively. It was obvious that SHMP caused more reduction in ionic Calcium than TSC.

Table 1. The effect of added TSC and SHMP on ionic calcium reduction in milk at $25^{\circ} \mathrm{C}$

\begin{tabular}{lll}
\hline Sequestering agent & ConcentrationmM) & *Free ionic Ca $(\mathbf{m M})$ \\
\hline TSC & 0.00 & $1.336 \pm 0.92$ \\
& 0.68 & $1.198 \pm 0.63$ \\
& 1.36 & $1.104 \pm 0.81$ \\
& 1.70 & $0.933 \pm 0.69$ \\
SHMP & 0.00 & $1.336 \pm 0.87$ \\
& 0.33 & $1.165 \pm 0.93$ \\
& 0.65 & $1.074 \pm 0.64$ \\
& 0.82 & $0.956 \pm 0.79$
\end{tabular}

Values are expressed as mean $\pm \mathrm{SD}(\mathrm{n}=3)$. 


\section{Macrothink}

\subsection{Effect of Sequestering Agents on Calcium Reduction}

Table 4 indicates that $1.36 \mathrm{mM}$ and $2.72 \mathrm{mM}$ TSC reduced ionic calcium by 8.6 and $13.9 \%$, respectively, from control milk (without trypsin addition). However, at the same level of TSC in trypsin added sample, the ionic calcium was reduced by 10.4 and $17.0 \%$, respectively indicating lower Ca reduction. Addition of $0.65 \mathrm{mM}$ and $1.01 \mathrm{mM}$ SHMP, resulted in ionic calcium reduction by 17 and $31 \%$ from the control milk whereas 11 and $23 \%$ was reduced from trypsin treated samples. Based on these results, it is notable that addition of trypsin generally increased the ionic calcium level in milk.

Table 2. The effect of ionic calcium reduction by TSC and SHMP stored at $25^{\circ} \mathrm{C}$

\begin{tabular}{ll}
\hline Samples & *Free ionic Ca (mM) \\
\hline UHT Milk (No sequesters) & $1.309 \pm 0.57$ \\
UHT Milk with 1.36 mM TSC & $1.196 \pm 0.92$ \\
UHT Milk with 2.72 mM TSC & $1.127 \pm 0.46$ \\
UHT Milk with 0.65 mM SHMP & $1.083 \pm 0.68$ \\
UHT Milk with 1.31 mM SHMP & $0.904 \pm 0.05$ \\
UHT milk with trypsin (No sequesters) & $1.704 \pm 0.86$ \\
UHT Milk with trypsin and 1.36 mM TSC & $1.526 \pm 0.72$ \\
UHT Milk with trypsin and 2.72 mM TSC & $1.416 \pm 0.81$ \\
UHT Milk with trypsin and 0.65 mM SHMP & $1.520 \pm 0.61$ \\
UHT Milk with trypsin and 1.31 mM SHMP & $1.319 \pm 0.59$ \\
\hline
\end{tabular}

Values are expressed as mean $\pm \mathrm{SD}(\mathrm{n}=3)$.

\subsection{Effect of Sequestering Agent on Gelation}

Table 5 shows the gelation times of various UHT treated samples at $25^{\circ} \mathrm{C}$. It was interesting to note that only one sample inoculated with Pseudomonas fluorescens 416 (no sequesters) gelled on day 2, but none of the other samples inoculated with Pseudomonas fluorescens 416 with added sequestering agents gelled. 


\section{Macrothink}

Table 3. Gelation of UHT treated milk samples with sequestering agent stored at $25^{\circ} \mathrm{C}$

\begin{tabular}{|c|c|}
\hline Sample & Gelation day \\
\hline Ps. fluorescens 416 with $3.40 \mathrm{mM}$ TSC & NG \\
\hline Ps. fluorescens 416 with $6.80 \mathrm{mM}$ TSC & NG \\
\hline Ps.fluorescens 416 with $10.20 \mathrm{mM}$ TSC & NG \\
\hline Ps. fluorescens 416 with $1.63 \mathrm{mM}$ SHMP & NG \\
\hline Ps. fluorescens 416 with 3.27 mM SHMP & NG \\
\hline Ps. fluorescens 416 with $4.90 \mathrm{mM}$ SHMP & NG \\
\hline Ps. fluorescens 416 (NO SEQUESTERS) & 2 \\
\hline UHT with $3.40 \mathrm{mM}$ TSC & 5 \\
\hline UHT with $6.80 \mathrm{mM}$ TSC & 9 \\
\hline UHT with $10.20 \mathrm{mM}$ TSC & 9 \\
\hline UHT with $1.63 \mathrm{mM}$ SHMP & 9 \\
\hline UHT with $3.27 \mathrm{mM}$ SHMP & 9 \\
\hline UHT with $4.90 \mathrm{mM}$ SHMP & 12 \\
\hline UHT (NO SEQUESTERS) & 5 \\
\hline Chymosin UHT with $3.40 \mathrm{mM}$ TSC & 4 \\
\hline Chymosin UHT with 1.63mM SHMP & 5 \\
\hline Chymosin UHT (NO SEQUESTERS) & 0 \\
\hline
\end{tabular}

NG- no gelation observed; * all samples were observed in triplicates.

\subsection{The Effect of pH Reduction on Gelation of UHT Milk at $25^{\circ} \mathrm{C}$}

Figure 1 shows the $\mathrm{pH}$ of the various samples stored for 9 days. It is obvious that the $\mathrm{pH}$ was decreasing with time, with inoculated samples showing highest levels of decrease as compared to non-inoculated samples. 


\section{Ml Macrothink}

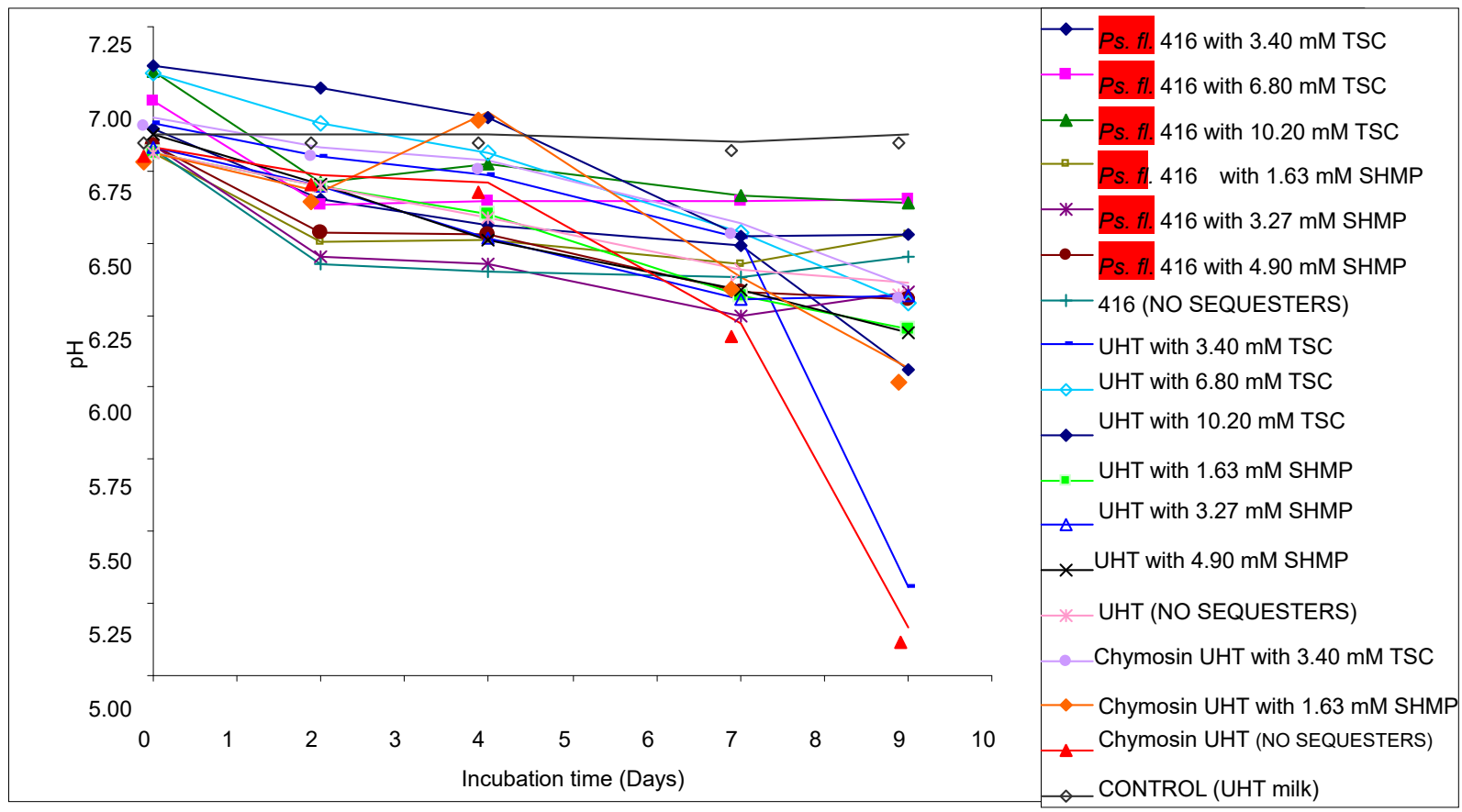

Figure 1. pH of UHT milk samples incubated with sequestering agents and Pseudomonas fluorescens 416 at $25^{\circ} \mathrm{C}$ for 9 days (* all samples were observed in triplicates)

\subsection{Effect of Sequestering Agent on Proteolysis}

The effect of sequestering on proteolysis of milk samples are shown in Figures 2 and 3. With a few exceptions the degree of proteolysis increased with time for all samples except the control sample which remained constantly low throughout the incubation time. Proteolysis in latter samples was low (less than $140 \mathrm{mAU}{ }^{*} \mathrm{~min}$ ), possibly from activities of native enzymes in milk (Datta \& Deeth, 2003; Nielsen, 2002). There was no clear relationship between the effect of proteolysis with either the type or quantity of sequestering agent added in non-inoculated samples. As both sequesters showed increased proteolysis with time, this suggests that in the current study sequestering agents did not influence proteolysis. 




Figure 2. Proteolysis of $\mathrm{pH} 4.6$ soluble extracts of UHT skim milk with added sequestering agents analysed by the RP-HPLC method (* all samples were observed in triplicates)



Figure 3. Proteolysis of $\mathrm{pH} 4.6$ soluble extracts of UHT skim milk inoculated with Pseudomonas fluorescens 416 (with sequestering agents) analysed by the RP-HPLC method (*all samples were observed in triplicates)

\section{Discussion}

\subsection{The Effect of Ionic Calcium Reduction by Sequestering Agents on Gelation}

TSC was less effective in lowering the level of ionic calcium as compared to SHMP, which caused higher reduction in ionic calcium. A study on soymilk revealed that increasing SHMP concentration reduced $\mathrm{Ca}$ ion concentration (Faka et al., 2009; Pathomrungsiyounggul et al., 


\section{MInstitute ${ }^{\text {Mink }}$}

2007). Similar results were also observed from the work of Tsioulpas (2005) who stated that SHMP had a strong chelating effect in milk. In one study it was revealed that TSC treated samples gelled more rapidly than either controls or samples with added SHMP (Kocak \& Zadow, 1985). The researchers concluded that TSC accelerated age-gelation, although they did not explain the mechanism. It was probably due to its lower affinity for calcium ions in comparison to SHMP.

\subsection{The Effect of pH Reduction on Gelation of UHT Milk at $25^{\circ} \mathrm{C}$}

The observed finding that $\mathrm{pH}$ decreased steadily with incubation time was also reported previously (Kocak \& Zadow, 1985). The only exceptions were the two samples whose $\mathrm{pH}$ was below 5.5 on the 9 th day, since most samples had a $\mathrm{pH}$ of above $6.25 \pm 0.02$ during incubation. As the two samples with the lowest $\mathrm{pH}$ values (UHT milk with $3.40 \mathrm{mM}$ TSC and $0.03 \%$ chymosin treated UHT milk without sequesters) did not show any relationship in terms of treatments, it is suggested that the $\mathrm{pH}$ drop was most probably due to bacterial contamination as sodium azide was not used. The control sample however, was constant (6.77 \pm 0.02$)$ throughout storage. It was observed that TSC increased the $\mathrm{pH}$ of the samples on day 0 and the increament was direct proportional to concentration (Figure 1). However, the $\mathrm{pH}$ eventually decreased with time.

It has been previously reported that TSC increases the $\mathrm{pH}$ of samples ( Faka et al., 2009; Tsioulpos, 2005 ). This is achieved because the reduction in ionic calcium caused by TSC lowers the ionic calcium in the serum and this will increases the $\mathrm{pH}$ to maintain equilibrium as shown in the equation suggested by (Horne, 2003)

$$
3 \mathrm{Ca}^{2+}+2 \mathrm{HPO}_{4}{ }^{2-} \leftrightarrow \mathrm{Ca}_{3}\left(\mathrm{PO}_{4}\right)_{2}+2 \mathrm{H}^{+}
$$

The same mechanism was described during acidification. In the serum, calcium exists bound with either phosphate or citrate, or as free calcium ions, whereas in the colloidal phase it exists as colloidal calcium phosphate (CCP). Calcium and phosphorus migrate from the micelle and calcium phosphate becomes more soluble. This results in increase of free ionic calcium, causing liberation of hydrogen ions and decrease in $\mathrm{pH}$ (Augustin \& Clarke, 1990). The distribution of caseins and calcium between the serum and micellar phase is $\mathrm{pH}$ and temperature dependent. Furthermore, upon acidification casein micelles lose their colloidal stability and start to aggregate and gel. Vasbiner et al. (2003) studied two methods of acid-induced gelation: acidification of milk at temperatures of 20 to $50{ }^{\circ} \mathrm{C}(\mathrm{T}-\mathrm{pH})$ and decreasing the $\mathrm{pH}$ at $20^{\circ} \mathrm{C}$ to just above the gelation $\mathrm{pH}$ and subsequently inducing gelation by increasing the temperature $(\mathrm{pH}-\mathrm{T})$. It was revealed that gelation kinetics and the properties of the final gels obtained are affected by the gelation route applied. The $\mathrm{pH}-\mathrm{T}$ milks gelled at higher $\mathrm{pH}$ and lower temperature and the gels formed are stronger and show less susceptibility to syneresis

\subsection{The Effect of Ionic Calcium Reduction in UHT Milk on Gelation at $25{ }^{\circ} \mathrm{C}$}

Trypsin, chymosin and Pseudomonas fluorescens 416 were used so as to accelerate proteolysis and gelation and to determine the lowest level of ionic calcium responsible for gelation.

It is obvious form Table 4 that addition of trypsin increased the ionic calcium level in milk. The possible explanation is that when trypsin was added to milk, it disrupted the casein micelles. This would cause shift in equilibrium of ionic calcium between the soluble and colloidal phase. 


\section{Macrothink}

The colloidal calcium phosphate precipitates causing calcium ion liberation in the serum (Lin et al., 2006). This is an important finding which needs further investigation. Lack of gelation observed in samples inoculated with Pseudomonas fluorescens 416 even after 9 days of storage gelation on day 2 with Pseudomonas fluorescens without sequesters indicates the role of the bacterial proteases to gelation. Investigation into the gelation of milk by Pseudomonas fluorescens proteinases confirmed that a gel formed depending on the activity of the organism before heat treatment ( Costa et al., 2002; Law, 1979; Law et al., 1977) ,. It was also revealed that proteases from psychrotrophic bacteria are capable of causing gelation of UHT milk (Cogan, 1977). Therefore, it may be concluded that enzymes from the Pseudomonas fluorescens 416 initiated proteolysis causing gelation in the sample without sequestering agents. Furthermore, lack of gelation for samples with added sequestering agents could be due to low levels of calcium found in these samples. This is an interesting finding which indicates the possible role of ionic calcium to gelation. It may thus be concluded that proteolysis caused by Pseudomonas fluorescens 416 in this study was not able to cause gelation. Calcium is critical for milk gelation. It is possible that sequestering agents inhibited bacterial activity. This needs further investigation. Research has shown that proteinases from psychrophic bacteria, mostly Pseudomonas spp are stable at room temperature but survive pasteurisation and UHT treatment (Chavan et al., 2011). Further study on this is significant because it has an implication on milk that might be required for yoghourt or other fermented milk products. It would be interesting to observe the influence of higher levels of proteinases on milk with reduced ionic calcium.

It is also obvious from the table that gelation was delayed in UHT milk samples with sequesters, whereby the lower the concentration of the sequestering agents, the longer the time for gelation and vice-versa. It was also obvious that milk without sequestering agents gelled earlier than the rest because of the role of ionic calcium on gelation. However, some researchers did not find any correlation between ionic calcium with onset of gelation (Kocak \& Zadow, 1985). The sample that gelled on day 12 however was from the highest SHMP used. The delayed gelation observed in SHMP is in accordance with previous findings by Datta and Deeth (2001).

The chymosin treated sample (without sequesters) gelled on the same day of incubation compared to samples with sequestering agents which gelled on the 4th and 5th day. This confirms that although chymosin is crucial for proteolysis and gelation, a critical concentration of ionic calcium is required to initiate this process. This finding is of high significance for cheese manufacture. It was revealed that rennet coagulation time was lower for milk with a higher $\mathrm{Ca}^{2+}$ concentration, but curd firmness was not related to $\mathrm{Ca}^{2+}$ concentration (Datta \& Lewis, 2015). There was a poor correlation between the $\mathrm{pH}$ reduction caused by acid addition and that resulting from increasing temperature. Sediment formation was related to $\mathrm{pH}$ change at high temperature (Lewis, 2011). It was concluded from one study that the nature of the calcium- and heat-induced gelation or coagulation of milk is influenced, and can be manipulated, by a combination of factors including ionic calcium concentration, temperature, milk pH and milk solids level (Deeth \& Lewis, 2015). The technology of manufacturing calcium-induced milk coagulums and gels has potential for the development of novel dairy products (Lakshmi, 2013). 


\subsection{Effect of Proteolysis of UHT Milk at $25^{\circ} \mathrm{C}$}

The information should highlight the relationship between ionic calcium reduction by sequestering agents and bacterial activity with proteolysis which will confirm the role of ionic calcium reduction to gelation and proteolysis. UHT milk was used because it was concluded from previous studies that processing at higher temperature lowered proteolysis and hence susceptibility of UHT milk to spoilage (Chove et al., 2013, 2014). This is probably through denaturation of enzymes responsible for proteolysis, hence decreased proteolysis.

This trend is unclear but it may be due to complexing of SHMP or TSC with the breakdown products formed during proteolysis.

Although inoculated samples had higher rates of proteolysis than non-inoculated samples, no clear relationship could be established between proteolysis and gelation at the levels of sequestering agents used in the current study. Neither did the ionic calcium reduction in this study confirm the relationship with proteolysis. Although samples inoculated with Pseudomonas fluorescens without added sequesters gelled on day 2 (as explained above), Figure 3 shows that they had the lowest rate of proteolysis. Studies regarding the link between proteolysis and gelation are inconclusive. It has been reported that addition of SHMP $(0.1 \%)$ did not influence the rate of proteolysis, but inhibited the aggregation process (Kocak \& Zadow, 1985). It was confirmed in a study that the stabilising effect of SHMP was independent of proteolysis in unconcentrated UHT milk (Snoeren et al., 1979). Datta and Deeth (2001) stated that although SHMP inhibited gelation, it did not affect proteolysis. It was documented that addition of $0.15 \mathrm{mg} / \mathrm{L}$ plasmin caused gelation of UHT milk in 90 days (Kohlmann et al., 1991), indicating the significance of minor proteolysis by plasmin prior to gelation (Chove et al., 2011). It was also revealed that neither gelation nor proteolysis $\left(9\right.$ months at $\left.20{ }^{\circ} \mathrm{C}\right)$ was observed in a study where serine protease inhibitors were added to UHT skim milk to inhibit plasmin activity, implicating the role of plasmin in proteolysis preceding gelation (De Koning et al., 1985). Longer observation time at $20-25{ }^{\circ} \mathrm{C}$ would be more useful to study the effect of storage on proteolysis and gelation.

\section{Conclusion}

This paper highlighted the role of sequestering agents in ionic calcium reduction and how this influenced gelation and/or proteolysis. Results demonstrated that addition of sequestering agents reduced ionic calcium in the samples through the formation of complexes with the ions. SHMP reduced more ionic calcium than TSC in UHT milk as it has more chelating power. Ionic calcium reduction was in most cases accompanied by an increase in $\mathrm{pH}$ which was most evident with TSC at $25^{\circ} \mathrm{C}$. Gelation of non-inoculated samples on day 2 indicates the role of $\mathrm{Ca}$ in gelation.

Trypsin, chymosin and Pseudomonas fluorescens 416 were used to accelerate proteolysis. Increased ionic calcium in trypsin treated samples requires more investigation. Although proteolysis was higher in samples inoculated with Pseudomonas fluorescens 416, no clear relationship was established between proteolysis and gelation in UHT milk.

This study has shown some indication of the role of ionic calcium levels to proteolysis and gelation. However, longer time study using sodium azide to prevent bacterial contamination 


\section{MInstitute ${ }^{\text {Macrothink }}$}

would be required to confirm these findings and give more comprehensive results and conclusion.

\section{References}

Augustin, M. A., \& Clarke, P. T. (1990). Effects of added salts on the heat-stability of recombined concentrated milk. Journal of Dairy Research, 57, 213-226. https://doi.org/10.1017/S0022029900026820

Browning, E., Lewis, M. J., \& Macdougall, D. (2001) Predicting safety and quality parameters for UHT -processed milks. International Journal of Dairy Technology, 54, 111-120. https://doi.org/10.1046/j.1364-727x.2001.00021.x

Chen, L., Daniel, R. M., \& Coolbear, T. (2003) Detection and impact of protease and lipase activities in milk and milk powders. International Dairy Journal, 13, 255-275. https://doi.org/10.1016/S0958-6946(02)00171-1

Chove, L. M., Grandison, A. S., \& Lewis, M. J. (2011). Comparison of the methods for analysis of proteolysis by plasmin in milk. Journal of Dairy Research, 78, 184-190. https://doi.org/10.1017/S0022029911000094

Chove L. M., Issa- Zacharia, A., Grandison A. S., \& Lewis, M. J. (2013). Proteolysis of milk heated at high temperatures by native enzymes analysed by trinitrobenzene sulphonic acid (TNBS) method. African Journal of Food Science, 7(8), 232-237. https://doi.org/10.5897/AJFS13.0987

Chove, L. M., Grandison, A. S., Lewis, M. J., \& Issa- Zacharia, A. (2014). Detection of proteolysis in high temperatures treated milk by Reverse Phase High Performance Liquid Chromatography (RP-HPLC). African Journal of Food Science, 8(2), 80-86. https://doi.org/10.5897/AJFS2013.1089

Costa, M., Gomez, M. F., Molina, L. H., Simpson, R., \& Romero, A. (2002). Purification and characterization of proteases from Pseudomonas fluorescens and their effect on milk proteins. Archivos Latinoamericanos de Nutricion, 52, 160-166.

Datta, N., \& Deeth, H. C. (2003). Diagnosing the cause of proteolysis in UHT milk. $\begin{array}{llll}\text { Lebensmittel-Wissenschaft und } \quad \text {-Technologie, } & 36, & 173-182 .\end{array}$ https://doi.org/10.1016/S0023-6438(02)00214-1

Deeth, H. C., \& Lewis, M. (2001). Age gelation of UHT milk. Food and Bioproduct processing, 79, 197-210. https://doi.org/10.1205/096030801753252261

Deeth, H. C., \& Lewis, M. (2015). Practical consequences of calcium addition to and removal from milk and milk products. International Journal of Dairy Technology, 65(1), 1-10. https://doi.org/10.1111/1471-0307.12188

Faka, M., Lewis, M. J., \& Grandison, A. S. (2009). The effect of free Ca2p on the heat stability and other characteristics of low-heat skim milk powder International Dairy Journal, 19, 386-392. https://doi.org/10.1016/j.idairyj.2008.12.006

Holt, C., Dangleish, D. G., \& Jennes, R. (1981). Calculation of ionic equilibria in milk diffusate and comparison with experiment. Analytical Biochemistry, 113, 154-163. https://doi.org/10.1016/0003-2697(81)90059-2 


\section{Macrothink

Hyslop, D. B. (2003). Enzymatic coagulation of milk. In P. F. Fox, \& P. L. H. Mcsweeney, (Eds.) Advanced Dairy Chemistry Volume I Proteins. New York, Kluver Academic/Plenun Publishers. https://doi.org/10.1007/978-1-4419-8602-3_24

Kohlmann, K. L., Nielsen, S. S., \& Ladisch, M. R. (1991). Purification and characterisation of an extracellular protease produced by Pseudomonas fluorescens M3/6. Journal of Dairy Science, 74, 4125-4136. https://doi.org/10.3168/jds.S0022-0302(91)78607-4

Lakshmi, R. (2013). The interaction of ionic calcium and milk proteins during heat treatment $\mathrm{PhD}$ Thesis, School of Agriculture and Food Sciences, The University of Queensland.

Law, B. A. (1979). Reviews on the progress of Dairy Science: Enzymes of pschrotrophic bacteria and their effects on milk and milk products. Journal of Dairy Research, 46, 573-588. https://doi.org/10.1017/S0022029900017611

Law, B. A., Andrews, A. T., \& Sharpe, M. E. (1977). Gelation of ultra-high temperature-sterilised milk by proteinases from a strain of Pseudomonas fluorescens isolated from milk. Journal of Dairy Research, 44, 145-148. https://doi.org/10.1017/S0022029900020057

Manji, B., \& Kakuda, Y. (1988). The role of protein denaturation, extent of proteolysis and storage temperature on the mechanism of age gelation in a model system. Journal of Dairy Science, 71, 1455-1463. https://doi.org/10.3168/jds.S0022-0302(88)79708-8

Manji, B., Kakuda, Y., \& Arnott, D. R. (1986). Effect of storage temperature on age gelation of ultra-high temperature milk processed by direct and indirect heating systems. Journal of Dairy Science, 69, 2994-3001. https://doi.org/10.3168/jds.S0022-0302(86)80761-5

Nielsen, S. S. (2002). Plasmin system: characteristic, roles, and relationships. Journal of Agriculture and Food Chemistry, 50, 6628-6634. https://doi.org/10.1021/jf0201881

Patel, T. R., Jackman, D. M., Williams, G. J., \& Martlett, F. M. (1986). Extracellular heat resistant proteases of psychrotrophic Pseudomonads. Journal of Food Protection, 49, 183-188. Schokker, E. P., \& Van Boekel, M. A. J. S. (1997). Production, purification and partial characterisation of the extracellular proteinase from Pseudomonas fluorescens $22 \mathrm{~F}$. International Dairy Journal, 7, 265-271. https://doi.org/10.4315/0362-028X-49.3.183

Sharma, V., \& Sindhu, J. S. (2001). Physical propeties of milk as influenced by the alteration in ionic calcium and magnesium. Indian Journal of Dairy Science, 54, 19-22.

Snoeren, T. H. M., \& Van Riel, J. A. M. (1979). The properties of $\alpha_{\mathrm{S} 2}$-group casein. Zuivelzicht, 71, 766-768.

Van Hooydonk, A. C. M., Hagerdoorn, H. G., \& Boerrigter, I. J. (1986). The Effect Of Various Cations On Renneting Of Milk. Netherlands Milk And Dairy Journal, 40, 369-390. 


\section{IIMacrothink}

\section{Appendix 1}

Calibration curve for free ionic calcium as analysed by the ionic calcium analyser

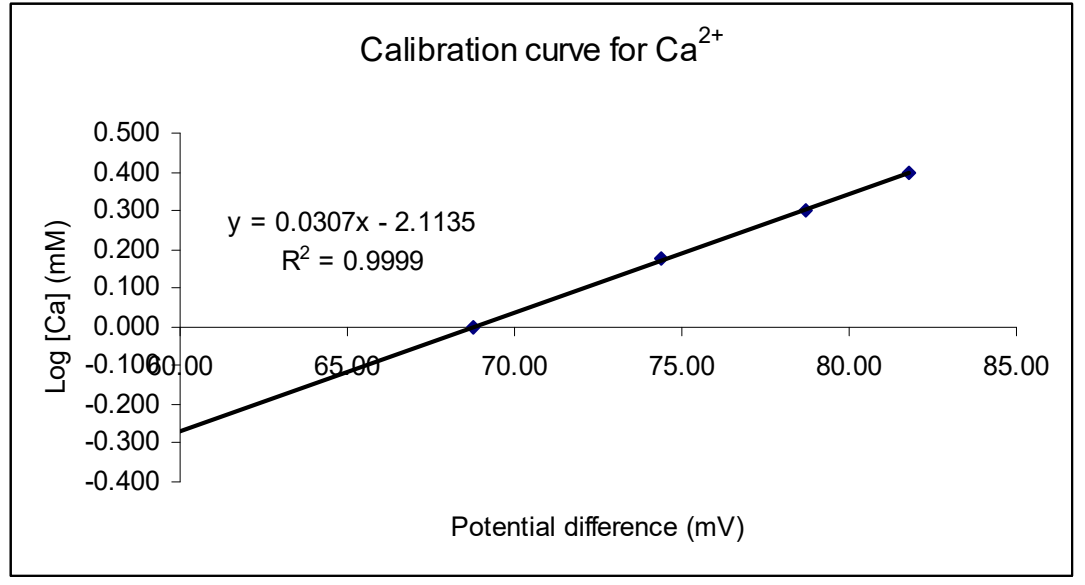

Calibration curve for free ionic calcium as analysed by the ionic calcium analyser

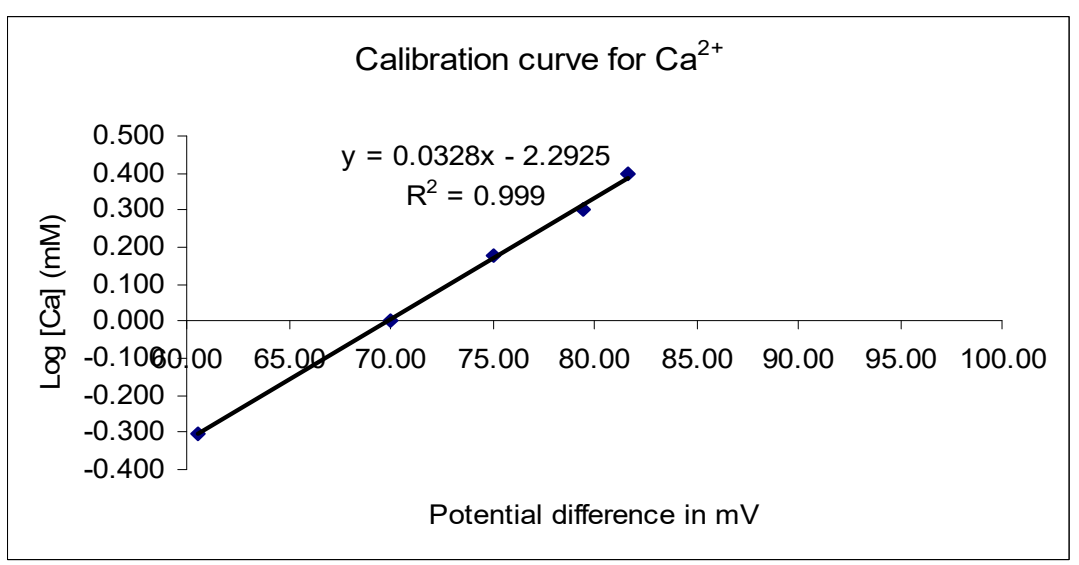

Calibration curve for free ionic calcium as analysed by the ionic calcium analyser

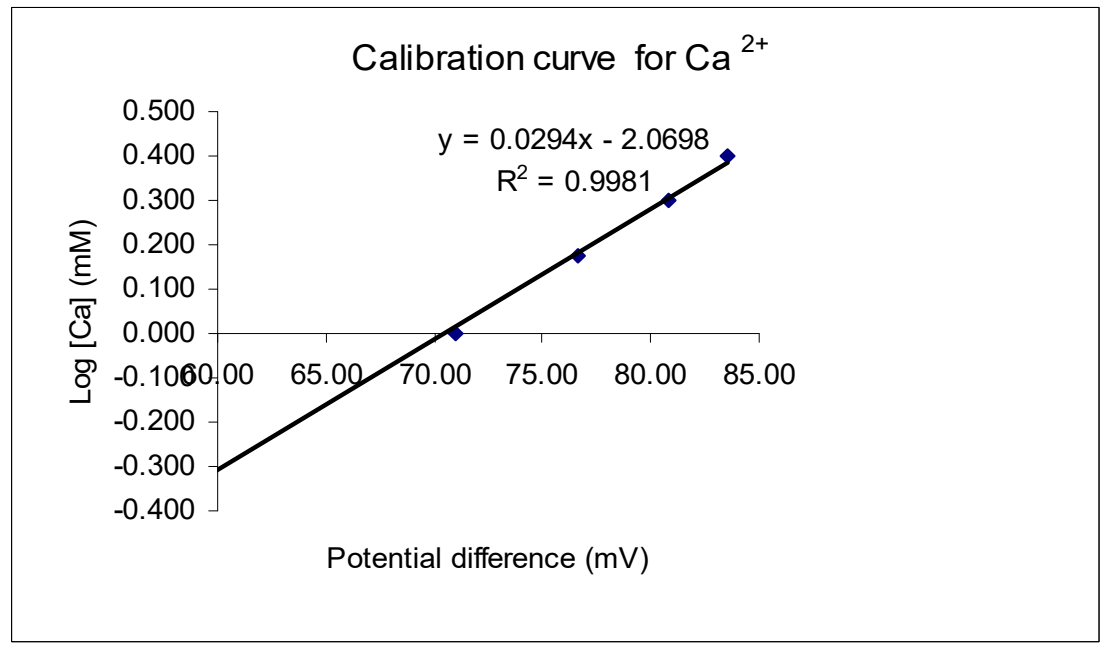




\section{Macrothink}

\section{Copyright Disclaimer}

Copyright for this article is retained by the author(s), with first publication rights granted to the journal.

This is an open-access article distributed under the terms and conditions of the Creative Commons Attribution license (http://creativecommons.org/licenses/by/3.0/). 